\title{
John G. Diefenbaker and Cross Border Relations During the Bomarc Missile Crisis
}

\author{
Sarah Empey
}

In February 1963, the United States (U.S.) embassy telegrammed the Department of State to declare that the "neurotic Canadian view of the world and of Canadian role" had been tolerated for too long and that "Prime Minister Diefenbaker [was] determined [to] carry on in dream world as long as possible."1 In contrast to the heightened tensions between Canadian-U.S. relations during the Kennedy presidency just four years earlier, during the Eisenhower presidency, bilateral relations were friendly. ${ }^{2}$ During his time in office from 1957 to 1963 , the quality of Prime Minister Diefenbaker's relationship with the contemporary U.S. President strongly influenced the nature of bilateral relations between Canada and the United States. To determine the extent of these relations in the context of the Bomarc Missile Crisis, this paper will examine Diefenbaker's relationship with Presidents Eisenhower and Kennedy respectively. The analysis of this will be divided into four sections: Bilateral relations in the context of the Bomarc Missile Crisis, a historiographical analysis of the crisis, and an analytical comparison of Diefenbaker's respective relations with U.S. Presidents Eisenhower and John F. Kennedy.

\section{Bilateral Relations in the Context of the Bomarc Missile Crisis}

\footnotetext{
${ }^{1}$ U.S. Department of State, Foreign Relations Documents, 445 Telegram From the Embassy in Canada to the Department of State, by Walton W. Butterworth, February 3, 1963, https://history.state.gov/historicaldocuments/frus1961-63v13/d445.

${ }^{2}$ U.S. Department of State, Foreign Relations Documents, 304, Telegram From the Embassy in Canada to the Department of State, August 29, 1959, https://history.state.gov/historicaldocuments/frus1958-60v07p1/d304.
} 
John G. Diefenbaker, leader of the Conservative Party of Canada, was elected Canada's Prime Minister on June 17, 1957 at 61 years old. ${ }^{3}$ He came to power in the middle of the Cold War and as such, one of his first actions as Prime Minister was the establishment of the North American Air Defense Agreement (NORAD) with the United States, to secure the protection of the North American continent from Soviet bombers. ${ }^{4}$

The Bomarc Missile Crisis began in August 1958 with the cancellation of the AvroArrow, a Canadian-designed aircraft interceptor, following cabinet's approval of the Americanmade Bomarc missile as a more suitable weapon for Canadian defence. ${ }^{5}$ In addition to regular weaponry, the Bomarc could also be armed with nuclear warheads, which made it a powerful surface-to-air, anti-aircraft missile. ${ }^{6}$ As a potential nuclear weapon, the Bomarc was also capable of disarming Soviet attacks directed at the United States. ${ }^{7}$ This ability to protect both Canada and the U.S. from Soviet attacks made the Bomarc key to NORAD. ${ }^{8}$

While there was some initial Canadian opposition to its implementation, this was primarily stimulated by the 25000 Canadian jobs that would disappear with the replacement of the Avro-Arrow, rather than concerns about its nuclear capabilities. ${ }^{9}$ Despite the initial loss of

\footnotetext{
3 “Diefenbaker, John George," Dictionary of Canadian Biography, 2015, Accessed Friday, November 27, 2015, http://www.biographi.ca/en/bio/diefenbaker_john_george_20E.html.

${ }^{4}$ Ibid.

${ }^{5}$ Dennis Smith, Rogue Tory: The Life and Legend of John J. Diefenbaker, (Toronto, Ontario: Macfarlane, Walter \& Ross, 1995), 310.

${ }^{6}$ James G. Fergusson, Canada and Ballistic Missile Defense, 1954 - 2009: Déjà Vu All Over Again, (Vancouver, British Columbia: University of British Columbia Press, 2010), 20. \& "Diefenbaker, John George," Dictionary of Canadian Biography, 2015.

${ }^{7}$ U.S. Department of State, Foreign Relations Documents, 444 Department of State Press Release no. 59 - United States and Canadian Negotiations Regarding Nuclear Weapons, January 30, 1963, https://history.state.gov/historicaldocuments/frus1961-63v13/d444.

${ }^{8}$ U.S. Department of State, Foreign Relations Documents, 445 Telegram From the Embassy in Canada to the Department of State, by Walton W. Butterworth, February 3, 1963.

${ }^{9}$ Smith, Rogue Tory, 312.
} 
the Avro-Arrow jobs and the rise of anti-nuclear groups such as the Voice of Women (VOW), Canadians largely supported the acquisition of the Bomarc and nuclear weapons in general. ${ }^{10}$

Although opinion polls in 1961 suggested that $46 \%$ of Canadians were in favour of nuclear weapons, Diefenbaker became consumed with the $20 \%$ opposition who wrote to him. Rather than paying attention to the polls, Diefenbaker chose to focus on the anti-nuclear correspondence he received, which historian Patricia McMahon suggests was largely organized by small opposition groups like VOW. ${ }^{11}$ This correspondence had a strong effect and caused Diefenbaker to believe he would tarnish his political image if he pushed for the acquisition of the Bomarc. $^{12}$

In addition to concerns about his public image, Diefenbaker was also preoccupied with the deep division that the Bomarc caused within his cabinet. Howard Green, Norman Robertson, and Douglas Harkness were the three principal actors that divided Diefenbaker's cabinet. Though both Green the head of External Affairs, and Robertson the Undersecretary of External Affairs, strongly advocated non-proliferation, Harkness, who headed the Department of National Defense, did not. ${ }^{13}$ In contrast to Green and Robertson, Harkness strongly believed in the defensive value of nuclear weapons. ${ }^{14}$ Neither Green nor Harkness were willing to compromise on Canada's nuclear policy and as a result Harkness resigned from his position in early $1963 .{ }^{15}$

At the same time that the government attempted to determine Canada's nuclear policy, Green advocated non-proliferation in the United Nations (UN). This worried the Prime Minister,

\footnotetext{
${ }^{10}$ Patricia McMahon, Essence of Indecision: Diefenbaker's Nuclear Policy, 1957 - 1963, (Kingston, Ontario: McGill-Queen's University Press, 2009), 78 \& 92.

${ }^{11}$ Ibid.

${ }^{12}$ Ibid., 125 .

${ }^{13}$ Ibid., 55 \& 86.

${ }^{14}$ Ibid.

${ }^{15}$ Ibid., 477.
} 
who was concerned that if his government signed a definitive agreement for the Bomarc, it would undermine Green's and thus Canada's credibility at the UN. ${ }^{16}$

Both Diefenbaker's concerns and the division of his cabinet played an instrumental role in the delay of Canada's acquisition of the Bomarc missile. The deadlock of Canada's nuclear policy was ultimately, only broken by Lester B. Pearson, who defeated Diefenbaker's government in April 1963. ${ }^{17}$

\section{A Historiographical Analysis of the Bomarc Missile Crisis}

In recent literature, there are two books that illuminate the nature of Diefenbaker's government during the Bomarc Missile Crisis, and one that contributes specifically to Canada's relationship with missile defense. The following historiographical portion of this paper will examine Patricia McMahon's Essence of Indecision - Diefenbaker’s Nuclear Policy, 1957-1963, Dennis Smith's Rogue Tory: The Life and Legend of John G. Diefenbaker, and James Fergusson's Canada and Ballistic Missile Defense 1954-2009, in the context of the Bomarc Missile Crisis.

Patricia McMahon's Essence of Indecision - Diefenbaker's Nuclear Policy, 1957-1963 examines the Diefenbaker government's stance on nuclear weapons between 1957 and 1963. Despite the title's suggestion that Diefenbaker's nuclear policy was based on indecision, McMahon argues that Diefenbaker strongly supported Canada's acquisition of nuclear weapons. She emphasizes that his government's hesitation was prompted by political concerns rather than doubts about the value of nuclear weapons as a defense mechanism for Canada. ${ }^{18}$ For her, 'the

\footnotetext{
${ }^{16}$ McMahon, Essence of Indecision, 87.

17 “Diefenbaker, John George," Dictionary of Canadian Biography, 2015.

${ }^{18}$ McMahon, Essence of Indecision, Xii.
} 
essence of indecision' thus refers to the perception that Diefenbaker was indecisive and her argument ultimately attempts to clarify this as a misconception. ${ }^{19}$

To support her argument, she chronologically examines Diefenbaker's nuclear policy beginning with a brief discussion of how he won his 1958 majority government. ${ }^{20}$ She then quickly transitions into an analysis of his government's defense policy from 1958-1959 in the second chapter, arguing that the government's decision to simultaneously promote nuclear disarmament and acquire Bomarc nuclear missiles was not contradictory but rather a 'twopronged' defense strategy. ${ }^{21}$ She furthers this argument in chapter three, stating that whereas Diefenbaker's promotion of nuclear disarmament was representative of his idealism, his support of nuclear armament represented his pragmatism. ${ }^{22}$ In addition, McMahon also argues in this chapter that Diefenbaker continued to support the Bomarc despite his concerns about both Canadian sovereignty over the missiles, and his political image. ${ }^{23}$ Her fourth chapter then focuses on the rising tensions between Diefenbaker and President John F. Kennedy, which exacerbated the deterioration of bilateral ties between Canada and the United States. ${ }^{24}$ In chapter five McMahon focuses most prominently on her thesis, and opens the chapter with a reiteration of how Diefenbaker continued to value nuclear weapons but was cautious because of concern about his 'political standing'. ${ }^{25}$ To support this, McMahon cites Diefenbaker's 1961 Halifax speech in which he attempted to sway Canadian opinion towards nuclear weapons as evidence of his unwavering opinion. ${ }^{26}$ McMahon concludes her piece with a discussion of the influence of

\footnotetext{
${ }^{19}$ McMahon, Essence of Indecision, Xii.

${ }^{20}$ Ibid., Chapter One, 3- 27.

${ }^{21}$ Ibid., 47.

${ }^{22}$ Ibid., 52.

${ }^{23}$ Ibid., Chapter Three: $51-85$.

${ }^{24}$ Ibid., Chapter Four: $86-113$.

${ }^{25}$ Ibid., 114.

${ }^{26}$ Ibid., 118.
} 
the Cuban Missile Crisis on Canadian nuclear policies and how Diefenbaker's slow response to the crisis deepened the rift between Canada and the United States. ${ }^{27}$

While McMahon's piece presents a convincing narrative that Prime Minister Diefenbaker did have a degree of resolve in Canada's acquisition of nuclear weapons, specifically the Bomarc, much of her evidence could also be used to argue the opposite. For instance, her suggestion that the government's simultaneous decision to promote nuclear disarmament while in the midst of negotiations with the U.S. for nuclear armament could easily be argued as mere indecision, rather than the 'two-pronged' plan she suggests. ${ }^{28}$ McMahon could have potentially solved this issue by analyzing the counter-argument throughout the book. However, her lack of analysis of the counter-argument suggests that she wished to ignore the flaws in her argument. Although piece is adequately supported, it nonetheless struggles to completely dismiss the argument that Diefenbaker was indecisive on the acquisition of Canadian nuclear weapons.

Dennis Smith's Rogue Tory: The Life and Legend of John G. Diefenbaker follows the biographical narrative of Prime Minister Diefenbaker. Smith addresses the inability of Diefenbaker and his government to make a decision during the Bomarc Missile Crisis. He ties the beginnings of Diefenbaker's indecision regarding the Bomarc-B missiles into a discussion on the future of the Avro Arrow, the Bomarc's non-nuclear predecessor. ${ }^{29}$ Then, he addresses the apex of the crisis within the context of the political disintegration of Diefenbaker's government ${ }^{30}$ Unlike McMahon's clear justification of Diefenbaker's indecision, Smith approaches the subject with far more objectivity. In his narration of the crisis, Smith neither criticizes Diefenbaker for his indecisive nature nor does he condone it, he merely offers a narrative of the

\footnotetext{
${ }^{27}$ McMahon, Essence of Indecision, 152-153.

${ }^{28}$ Ibid., 47.

${ }^{29}$ Smith, Rogue Tory, 310-325.

${ }^{30}$ Ibid., 464-480.
} 
facts surrounding the crisis. The only sense of bias that appears in the missile crisis discussion is through Smith's general favouring of Harkness. Although Smith never directly states that he sympathizes more with Harkness than Green, his general omission of Green's opinions within the discussion in contrast to the inclusion of direct quotations from Harkness, suggest that Smith is more sympathetic towards Harkness. ${ }^{31}$ Overall, Smith nonetheless offers a detailed description of the events and actors involved in the Bomarc Missile Crisis. As such, Smith's work offers valuable insight to the topic of this paper and is an excellent addition to the historiography of Diefenbaker's role in the Canadian acquisition of nuclear weapons.

In contrast to McMahon's micro-history of the Diefenbaker government's nuclear policies and Smith's biographical analysis of Diefenbaker's life, James Fergusson's Canada and Ballistic Missile Defense 1954-2009 presents a macro-history of Canada's nuclear defense policies over the course of fifty years. Fergusson's argument focuses on the Canadian governments' quiet, but reactionary approach to nuclear defence. He argues that governments remained silent when nuclear crises arose in order to, as he states, "avoid two perceived undesirable outcomes: an alienated ally [the United States] or a divided nation and government." ${ }^{32}$ In the preface to his book, he describes this mentality as 'national groupthink,' and presents the thesis of the book as an examination of how Canada became 'trapped' in the reactionary mindset that ultimately shaped Canadian nuclear policy. ${ }^{33}$

Fergusson divides his analysis into five chronologically organized 'acts.' Due to the broad time range covered in the book, only the first act of the work is relevant to this paper's discussion. The first act, titled “Anti-Ballistic Missiles: Don’t Worry, Be Happy (1954-71)," addresses Canadian nuclear policy between 1954 and 1971, which should have chronologically

\footnotetext{
${ }^{31}$ Smith, Rogue Tory, 469 \& 471.

${ }^{32}$ Fergusson, Canada and Ballistic Missile Defense, 2.

${ }^{33}$ Ibid., XV.
} 
captured Diefenbaker's role in the Bomarc Missile Crisis. However, despite its importance to Canada's acquisition of nuclear weapons the Bomarc Missile Crisis is only mentioned a handful of times. His only mention of the tensions that arose in the Canadian parliament between Howard Green and Douglas Harkness is written as an aside in the middle of a discussion on the state of NORAD in the late $1960 \mathrm{~s}^{34}$

Ultimately, the absence of the Bomarc Missile Crisis from the book draws the author's bias to the forefront. At the outset of the book Fergusson states: "I acquired the reputation as one of Canada's leading academic experts, and for good or ill, the most prominent academic proponent of Canadian participation [in ballistic missile defense]." 35 Fergusson's admission of his personal bias is commendable and adds legitimacy as it clarifies his personal standpoint; however it nonetheless reveals that he favors Canada's participation in nuclear defence. The lack of discussion on the Bomarc Missile Crisis thus suggests that Fergusson does not view the crisis as all that important, arguably because it did not immediately stimulate Canada's acquisition of nuclear weapons.

Although Fergusson's book is a valuable resource on Canada's relationship with ballistic missile defense, especially on missile technology, the lack of information on Diefenbaker's government makes it a less valuable resource for this paper. Furthermore, the absence of discussion on the Bomarc Missile Crisis suggests that despite its importance to Canada's relationship with nuclear weaponry, his bias persuaded him that it was not important enough to be included in the discussion of Canada and nuclear missiles.

For the purposes of this paper, McMahon's and Smith's books offer the most insightful contextual background to the Bomarc Missile Crisis and how it was affected by relations

\footnotetext{
${ }^{34}$ Fergusson, Canada and Ballistic Missile Defense, 44.

${ }^{35}$ Ibid., XIV.
} 
between Diefenbaker and the respective U.S. presidents. While Fergusson's piece illuminates the technicalities of the missiles Canada sought to or did acquire, his lack of analysis on the Bomarc in particular, prevents his work from being as useful as McMahon's or Smith's to the context of this paper.

\section{An Analytical Comparison of Diefenbaker's Respective Relations with U.S. Presidents Eisenhower and John F. Kennedy}

Although tensions between Canada and the U.S. were particularly high by 1963 , Diefenbaker and the U.S. had not always been on bad terms. In fact, bilateral relations between Canada and the US from 1957 to 1960 could even be described as friendly. In a comparison of how Diefenbaker's relationships with Eisenhower and Kennedy influenced relations between Canada and the U.S. during their respective presidencies, it is evident that Diefenbaker's perceptions of the U.S. President strongly impacted bilateral relations. This section of the paper will chronologically examine how Diefenbaker's relations with both presidents influenced bilateral relations between 1957 and 1963 in the context of the Bomarc Missile Crisis.

Though Canada's relations with the U.S. government during 1957 pre-date the beginning of the Bomarc Missile Crisis, the Diefenbaker government's activities in the summer of 1957 were nonetheless important as they set the stage for the crisis. In July 1957, Diefenbaker agreed without cabinet consultation that Canada would participate in NORAD - the mutual defense program that would make the Bomarc a viable defense option just one year later. ${ }^{36}$ In the summer of 1957, Diefenbaker made every effort to kindle a friendship with the U.S. government following his election. Relations were so amicable that after his first meeting with the new Prime Minister, U.S. ambassador Livingston Merchant described Diefenbaker as having "warmth,

\footnotetext{
36 “Diefenbaker, John George," Dictionary of Canadian Biography, 2015.
} 
eloquence and very real charm." ${ }^{37}$ Bilateral relations then continued to remain friendly throughout the negotiations for NORAD due to Diefenbaker's continued efforts to establish closeness with the U.S. ${ }^{38}$

Relations remained warm a year later when Eisenhower first visited Diefenbaker in Ottawa in July $1958 .{ }^{39}$ During the visit, Eisenhower, in addition to assuring the Prime Minister of the United States' respect for Canada, also built a personal friendship with Diefenbaker. ${ }^{40}$ Their friendship was so successful that Diefenbaker even spoke fondly of the President in his memoir stating: "President Eisenhower and I were from our first meeting on an 'Ike-John' basis, and that we were as close as the nearest telephone." ${ }^{41}$ Their friendship also influenced the officials around them and prompted the U.S. Secretary to thank George Pearkes, the Canadian Minister of National Defense, for his unique co-operation on matters of defense, a gesture that would be unheard of during Kennedy's presidency. ${ }^{42}$

It was in this amicable context that cabinet approved the acquisition of two Bomarc batteries in August $1958 .{ }^{43}$ In a show of further goodwill, the U.S. Department of Defense allowed Canadian companies to construct the two batteries and offered to pay two-thirds of the production cost, although the U.S. would maintain ownership of the missiles. ${ }^{44}$ This early agreement signaled to Washington that Canada was dedicated to the Bomarc program and

${ }^{37}$ U.S. Department of State, Foreign Relations Documents, 370. Memorandum of a Conversation Between Prime Minister Diefenbaker and the Ambassador in Canada (Merchant), Prime Minister's Office, Ottawa, June 22, 1957, by Livingston T. Merchant, June 22, 1957, https://history.state.gov/historicaldocuments/frus1955-57v27/d370.

${ }^{38}$ U.S. Department of State, Foreign Relations Documents, 377. Letter From the Secretary of State to the President, by John F. Dulles, July 29, 1957, https://history.state.gov/historicaldocuments/frus1955-57v27/d377.

${ }^{39}$ U.S. Department of State, Foreign Relations Documents, 280. Memorandum From Secretary of State Dulles to President Eisenhower, July 3, 1958. https://history.state.gov/historicaldocuments/frus1958-60v07p1/d280.

${ }^{40}$ U.S. Department of State, Foreign Relations Documents, 280. Memorandum From Secretary of State Dulles to President Eisenhower, July 3, 1958.

${ }^{41}$ John G. Diefenbaker, One Canada: Memoirs of the Right Honourable John G. Diefenbaker - The Years of Achievement, 1957 - 1962, (Toronto, Ontario: The Macmillan Company of Canada Ltd., 1976), 157.

${ }^{42}$ U.S. Department of State, Foreign Relations Documents, 287. Memorandum of Conversation - President's Visit to Canada, July 10, 1958, https://history.state.gov/historicaldocuments/frus1958-60v07p1/d287.

${ }^{43}$ Smith, Rogue Tory, 310.

${ }^{44}$ Ibid., 318-319. 
increased the warmth of relations on both sides of the border, as Diefenbaker felt that he had made a substantial stand of solidarity with the U.S. ${ }^{45}$

This is not to say that bilateral relations were always perfect, tensions certainly rose on occasions, but Diefenbaker and Eisenhower's friendship often smoothed tensions, as was the case with Operation Sky Hawk. Operation Sky Hawk was scheduled for October 1959, and was arguably seen as an indication of how the U.S. would test Bomarc missiles in the future. ${ }^{46}$ The operation was originally designed by the U.S. military in May 1959 to test NORAD's preparedness for any potential Soviet attacks. ${ }^{47}$ Although the test would have grounded Canadian civil aircraft, Canadian officials were not notified about Sky Hawk until August $1959 .{ }^{48}$ The late notification of the test deeply frustrated both Diefenbaker and his cabinet who refused to approve the test. ${ }^{49}$ If leaked media releases created tensions during 1962, it is certainly plausible that Sky Hawk could have easily created a rift in bilateral relations. However, due to Diefenbaker and Eisenhower's friendship, the two countries were able to work out their differences amicably. Once the U.S. realized the Diefenbaker government's agitation over Sky Hawk, U.S. Ambassador Richard Wigglesworth, rushed to Parliament Hill to privately explain the American position on behalf of Eisenhower. ${ }^{50}$ As a result of this expediency, and his personal respect for Eisenhower's position, Diefenbaker not only relaxed but also offered to reintroduce Sky Hawk to the cabinet. ${ }^{51}$ In Wigglesworth's memorandum of the conversation, it is obvious that Diefenbaker's respect for Eisenhower was key to his willingness to soothe tensions, which ultimately prevented a crisis.

\footnotetext{
${ }^{45}$ Smith, Rogue Tory, $321 \& 324$.

${ }^{46}$ McMahon, Essence of Indecision, 57.

47 Ibid.

${ }^{48}$ Ibid.

${ }^{49}$ Ibid.

${ }^{50}$ U.S. Department of State. Foreign Relations Documents. 304. Telegram From the Embassy in Canada to the Department of State, August 29, 1959. https://history.state.gov/historicaldocuments/frus 1958-60v07p1/d304 51 Ibid.
} 
In early 1960 bilateral relations remained cordial, even amidst concerns that the U.S. would cancel funding for the Bomarc program. ${ }^{52}$ This cordiality is evident in the very existence of the correspondence between the leaders. Rather than have a lower official inform Diefenbaker of the Bomarc's funding developments, Eisenhower took it upon himself to personally write and assure the Prime Minister that despite concerns, the Senate had ultimately approved \$244 million in funding. ${ }^{53}$ The nature of the letter also offers insight into the warmth of their friendship, as Eisenhower signed his letter stating: "With warm regard, Sincerely, Ike" to which Diefenbaker responded "Dear Ike, ...It was kind of you to write... With warmest regard, John." ${ }^{54}$ Further, Diefenbaker's self-described 'optimistic interest' in the funding for the Bomarc suggests that the Prime Minister was still committed to the implementation of the Bomarc missiles, arguably because of the warmth that their friendship had fostered between Canada and the U.S.

In his memoir, Diefenbaker remembered his friendship with Eisenhower as key to the good relations due to the President's respect for Canadians stating: "Eisenhower had been president for over four years when I formed my government in June 1957. I found Eisenhower a warm and engaging person and we became the best of friends. He had an appreciation of Canada and Canadians. ${ }^{~} 55$

Diefenbaker's amicability with the U.S. and his willingness to continue the Bomarc program disappeared following Kennedy's election, which had enormous effects on bilateral relations. The initial meeting between Diefenbaker and Kennedy, following the latter's election in November 1960, was polite if not particularly friendly. However this was most likely because

\footnotetext{
${ }^{52}$ John G. Diefenbaker, One Canada: Memoirs of the Right Honourable John G. Diefenbaker - The Tumultuous Years, 1962 - 1967, (Toronto, Ontario: The Macmillan Company of Canada Ltd., 1977), 59.

${ }^{53}$ Ibid. 59-60.

${ }^{54}$ Ibid., 60.

${ }^{55}$ Diefenbaker, One Canada - The Years of Achievement, 151-152.
} 
both parties left the meeting disillusioned. ${ }^{56}$ Whereas Kennedy believed that Diefenbaker had concretely promised to accept the Bomarc, Diefenbaker left the meeting certain that Kennedy would not pressure him to accept nuclear weapons. ${ }^{57}$

By Kennedy's visit to Ottawa in May 1961 the disillusionment of both parties had disappeared. ${ }^{58}$ In contrast to the amicable nature of Eisenhower's first visit to Canada in both public and private, the Kennedy visit was popular with the Canadian public. ${ }^{59}$ Privately, it is evident in the memorandum of their conversation that Kennedy was quite frustrated with his Canadian counterpart. During the meeting, Diefenbaker attempted to justify his reluctance to acquire the Bomarc on the basis of rising public opposition to a nuclear commitment. ${ }^{60}$ Rather than soothe his fears as Eisenhower had in the past, Kennedy downplayed and even mocked his concerns, implying that his fears were irrational and suggesting that Canadians who opposed nuclear weapons also defended Chinese communists. ${ }^{61}$ Whereas after Eisenhower's first visit to Canada, the leaders' friendship marked Canada and the U.S. as indispensible Cold War allies, at the end Kennedy's visit the leaders only seemed to agree upon the fact that the American public was more militant than its Canadian counterpart. ${ }^{62}$

Kennedy further muddied the waters in the fall of 1962 when his administration did not refute the Montreal Gazette headline "JFK Presses Canada on Nuclear Warheads," which exposed the previously secret negotiations to the Canadian public. ${ }^{63}$ The refusal of the Kennedy government to deny the headline for the sake of Diefenbaker had a profound effect on bilateral

\footnotetext{
${ }^{56}$ McMahon, Essence of Indecision, 86 \& 100-101.

${ }^{57}$ Ibid., 100.

${ }^{58}$ Ibid., 105.

${ }^{59}$ Ibid.

${ }^{60}$ U.S. Department of State, Foreign Relations Documents, 423. Memorandum of Conversation - Between President Kennedy and Prime Minister Diefenbaker - NATO and Nuclear Weapons, May 17, 1961, https://history.state.gov/historicaldocuments/frus1961-63v13/d423.

${ }^{61}$ Ibid.

${ }^{62}$ Ibid.

${ }^{63}$ McMahon, Essence of Indecision, 122.
} 
ties, as it deepened the Prime Minister's suspicions about Kennedy. ${ }^{64}$ Further, it made it politically impossible for Diefenbaker to accept the Bomarc without looking like he was bending to American pressure. ${ }^{65}$ Whereas the acquisition of the Bomarc had once appeared as an act of solidarity with the U.S. due to Diefenbaker and Eisenhower's friendship, the coldness between Diefenbaker and Kennedy now made nuclear association with America undesirable.

The fall of 1962 also brought with it the Cuban Missile Crisis, which, like Operation Sky Hawk, brought concerns about Canadian involvement in NORAD and in turn the Bomarc missiles. As with Sky Hawk, the U.S. did not officially inform Canadian officials about military operations until the last moment. Although Kennedy had known about the presence of Soviet missiles in Cuba since October 16, he failed to notify Diefenbaker until October $22 .{ }^{66}$ Diefenbaker interpreted this as a demonstration of how the U.S. government would behave in the case of a North American crisis, which would most likely involve the use of any Bomarc missiles on Canadian soil.${ }^{67}$ Not only did Kennedy fail to promptly notify his NORAD ally, he also failed to assure Diefenbaker of his country's respect for Canadian sovereignty, especially in the case of nuclear missiles like the Bomarc. This lack of reassurance left Diefenbaker to come to his own conclusions about American intentions, and as a result he delayed to offer substantial Canadian support to the U.S. during the Cuban Missile Crisis, which ultimately caused tension between the two countries. ${ }^{68}$

The situation between Diefenbaker and Kennedy, and the subsequent deterioration in bilateral ties, only continued to worsen in early 1963 . On January $25^{\text {th }} 1963$, Diefenbaker revealed to the House of Commons that Canada and the U.S. had been engaged in secret

\footnotetext{
${ }^{64}$ McMahon, Essence of Indecision, 122.

${ }^{65} \mathrm{Ibid}$.

${ }^{66}$ Ibid., 147-148.

${ }^{67}$ Ibid., 151.

${ }^{68}$ Ibid., 155.
} 
negotiations for the acquisition of the Bomarc and asserted that Canada should further slow down negotiations. ${ }^{69}$ Rather than attempt to clear up the matter privately as the U.S. ambassador had in the case of Sky Hawk, the U.S. quickly responded with a press release, which refuted the existence of such negotiations, and essentially called an infuriated Diefenbaker a liar. ${ }^{70}$ As tensions rose, the U.S. embassy telegrammed the U.S. State Department stating, "We should not be unduly disturbed at [the] steam of resentment which first blew off upon publication of [the] Department's release. Diefenbaker's reaction was expected. He is [an] undependable, unscrupulous political animal at bay and we are [the] ones who boxed him in." ${ }^{.71}$ Kennedy's subtle hostilities towards Diefenbaker as a result of his hesitation over the Bomarc program thus ultimately deteriorated bilateral ties to the point where U.S. officials felt unable to express their dislike of the Canadian government in a professional manner.

\section{Concluding Statements}

The warmth between Diefenbaker and Eisenhower from 1957 to early 1960 is truly remarkable when contrasted with Diefenbaker and Kennedy's frigid relations in the following three years. During his presidency Eisenhower struck up an honest friendship with Diefenbaker, which inspired a respect that lasted beyond their time in political office. Diefenbaker's respect for Eisenhower and the care U.S. officials took to allay his fears encouraged him to look upon the Bomarc program quite favourably even during potential crises, like Operation Sky Hawk. Due to his friendship with Eisenhower, Diefenbaker showed every sign of a desire to continue plans for the installation of the Bomarc in Canada, and even expressed concern about the

\footnotetext{
${ }^{69}$ U.S. Department of State. 443. Memorandum From the Assistant Secretary of State for European Affairs (Tyler) to the Under Secretary of State (Ball).

${ }^{70} \mathrm{McMahon}$, Essence of Indecision, 165.

${ }^{71}$ U.S. Department of State, Foreign Relations Documents, 445 Telegram From the Embassy in Canada to the Department of State, by Walton W. Butterworth, February 3, 1963.
} 
continuation of funding for the defense program. This mutual desire to work together for the protection of the North American continent ultimately established respect and friendship between Canada and the U.S. between 1957 and early 1960.

However, following Kennedy's election in November 1960, bilateral relations began to deteriorate as the frigidness between Diefenbaker and Kennedy stalled the installation of the Bomarc. Unlike Eisenhower, Kennedy did not attempt to soothe Diefenbaker's fears about potential American dominance of the Bomarc missiles. Instead, he continually aggravated Diefenbaker through his refusal to refute leaked information, his delay in notifying Canada about the Cuban Missile Crisis, and his department's publication of a statement which contradicted Diefenbaker's. This stimulated Diefenbaker's distrust of the U.S. and stalled the acquisition of the Bomarc, which raised tensions between Canada and the U.S. and deteriorated bilateral relations.

Diefenbaker's adjustment of his policy towards the acquisition of nuclear weapons was intrinsically tied to his relationship with the sitting U.S. president. When he had a friendship with the president, as he did with Eisenhower, he maintained an interest and even concern about the continuation of the Bomarc program. In contrast, when the U.S. president failed to soothe his fears and aggravated him, as with Kennedy, he stalled the Bomarc program. His attitude towards the acquisition of the Bomarc missiles then affected bilateral relations between the two countries. As such, Diefenbaker's relationships with the respective U.S. presidents demonstrate how relationships between national leaders have the ability to dramatically influence both shared defense policies and bilateral relations. 


\section{Bibliography}

Diefenbaker, John G. One Canada: Memoirs of the Right Honourable John G. DiefenbakerThe Years of Achievement, 1957 - 1962. Toronto, Ontario: The Macmillan Company of Canada Ltd., 1976.

Diefenbaker, John G. One Canada: Memoirs of the Right Honourable John G. DiefenbakerThe Tumultuous Years, 1962 - 1967. Toronto, Ontario: The Macmillan Company of Canada Ltd., 1977.

"Diefenbaker, John George." Dictionary of Canadian Biography. 2015. Accessed Friday, November 27, 2015. http://www.biographi.ca/en/bio/diefenbaker_john_george_20E.html.

Fergusson, James G. Canada and Ballistic Missile Defense, 1954 - 2009: Déjà Vu All Over Again. Vancouver, British Columbia: University of British Columbia Press, 2010.

Fortmann, Michel \& Legault, Albert. A Diplomacy of Hope: Canada and Disarmament, 1945 1988. Kingston, Ontario: McGill-Queen's University Press, 1992.

McMahon, Patricia. Essence of Indecision: Diefenbaker Nuclear Policy, 1957 - 1963. Kingston, Ontario: McGill-Queen's University Press, 2009.

Smith, Dennis. Rogue Tory: The Life and Legend of John J. Diefenbaker. Toronto, Ontario: Macfarlane, Walter \& Ross, 1995.

U.S. Department of State. Foreign Relations Documents. 370. Memorandum of a Conversation Between Prime Minister Diefenbaker and the Ambassador in Canada (Merchant), Prime Minister's Office, Ottawa, June 22, 1957, by Livingston T. Merchant, June 22, 1957. https://history.state.gov/historicaldocuments/frus1955-57v27/d370

U.S. Department of State. Foreign Relations Documents. 377. Letter From the Secretary of State to the President, by John F. Dulles, July 29, 1957.

https://history.state.gov/historicaldocuments/frus1955-57v27/d377

U.S. Department of State. Foreign Relations Documents. 280. Memorandum From Secretary of State Dulles to President Eisenhower, July 3, 1958.

https://history.state.gov/historicaldocuments/frus1958-60v07p1/d280

U.S. Department of State. Foreign Relations Documents. 287. Memorandum of ConversationPresident's Visit to Canada, July 10, 1958.

https://history.state.gov/historicaldocuments/frus1958-60v07p1/d287

U.S. Department of State. Foreign Relations Documents. 304. Telegram From the Embassy in Canada to the Department of State, August 29, 1959.

https://history.state.gov/historicaldocuments/frus1958-60v07p1/d304

U.S. Department of State. Foreign Relations Documents. 423. Memorandum of ConversationBetween President Kennedy and Prime Minister Diefenbaker - NATO and Nuclear 
Weapons, May 17, 1961. https://history.state.gov/historicaldocuments/frus1961$63 \mathrm{v} 13 / \mathrm{d} 423$

U.S. Department of State. Foreign Relations Documents. 443. Memorandum From the Assistant Secretary of State for European Affairs (Tyler) to the Under Secretary of State (Ball), January 29, 1963. https://history.state.gov/historicaldocuments/frus 1961-63v13/d443

U.S. Department of State. Foreign Relations Documents. 444. Department of State Press Release no. 59 - United States and Canadian Negotiations Regarding Nuclear Weapons, January 30, 1963. https://history.state.gov/historicaldocuments/frus1961-63v13/d444

U.S. Department of State. Foreign Relations Documents. 445. Telegram From the Embassy in Canada to the Department of State, by Walton W. Butterworth, February 3, 1963. https://history.state.gov/historicaldocuments/frus1961-63v13/d445 